\title{
QUALITY MANAGEMENT IN LIBRARIES CASE STUDY: BOOK COLLECTION RETRIEVAL IN ACADEMIC LIBRARIES
}

\author{
Vilianty Rizki Utami ${ }^{1}$ \& Desni Sri Hastuti Sihite ${ }^{2}$ \\ ${ }^{1}$ Universitas Indonesia, Jakarta \\ ${ }^{2}$ Universitas Bina Nusantara, Jakarta \\ Email: vilianty1203@gmail.com, desni.sihite@binus.edu
}

DOI: $10.24252 /$ kah.v9cf1

\begin{abstract}
ABSTRAK: Manajemen mutu di perpustakaan berhubungan dengan pengendalian mutu pekerjaan di perpustakaan untuk memenuhi harapan pengguna, dan memberikan kontribusi bagi keberhasilan organisasi yang berkelanjutan. Namun pengendalian mutu belum menjadi fokus utama di banyak perpustakaan. Penelitian ini bertujuan untuk menjelaskan bagaimana manajemen mutu dapat memperbaiki hasil pekerjaan di perpustakaan. Metode penelitian yang digunakan pada artikel ini adalah penelitian kualitatif dengan metode studi kasus. Peneliti melaksanakan penelitian di Perpustakaan X yang telah melakukan pengendalian mutu pada kegiatan Pengolahan buku tercetak. Metode Pengumpulan dan Analisis data dilakukan dengan cara analisa dokumen, observasi, dan wawancara pada kegiatan pengolahan buku dan data pengendalian mutu yang digunakan adalah data tahun 2018-2020. Hasil penelitian menunjukkan bahwa Perpustakaan $\mathrm{X}$ dapat meningkatkan kualitas kinerjanya dengan meningkatkan kualitas kegiatan Pengolahan buku dan memperbaiki kesalahan yang terjadi saat proses Pengolahan buku sebelum buku diletakkan pada rak layanan perpustakaan. Pengendalian mutu memberikan evaluasi yang komprehensif bagi kegiatan Pengolahan buku di Library X, baik dari segi sumber daya manusia, proses, dan sistem yang digunakan. Sehingga membantu Library X melaksanakan tugasnya dalam menyediakan kebutuhan informasi sesuai harapan penggunanya. Pengendalian mutu dan manajemen mutu juga dapat menggambarkan suasana kerja di Library X, dan dapat digunakan untuk memberikan motivasi kepada seluruh pustakawan dan staf perpustakaan agar memberikan layanan dan kinerja yang lebih baik bagi pengguna perpustakaan.
\end{abstract}

Kata Kunci: Manajemen mutu, pengendalian mutu, pengatalogan

ABSTRACT: Quality management in the library is related to quality control of the library's work to meet user expectations and contributes to the continued success of the organization. However, quality control is lacking and not be the main focus in many libraries. This paper aims to explain how quality management improves work results in libraries. The research method used in this paper is qualitative research using a case study method. We conduct research in Library $X$ that already underwent quality control in book processing activities. The data were collected through observation, and interviews for book processing activities and its quality control data during 20182020. The data was then analyzed document analysis. The study found that Library $X$ could perform better by improving the quality of book processing and fixing the error just before they put the book on its shelves. Quality control gives a comprehensive evaluation in Library X either for humans, processes, and systems of book processing activities that help Library $X$ conduct its duty to provide their user needs and expectations. Quality control and quality management also help Library $X$ describe the library working atmosphere and can be used for giving motivation to all librarians and staff to give better service and performance for the end-users.

Keywords: Quality management quality control, cataloguing 


\section{INTRODUCTION}

Library or information centers must always provide information resources and make them accessible to meet their users' needs (Ahmadi in Jabbari, Dizaji, Malekolkalam, 2021). ISO quality management principles (2015) explain that the primary focus of quality management is to meet customer requirements and to strive to exceed customer expectations. Continuous success is achieved when an organization attracts and retains the confidence of customers and other interested parties. Every aspect of customer interaction provides an opportunity to create more value for the customer. Understanding the current and future needs of customers and other interested parties contributes to the continued success of the organization (International Organization for Standardization, 2015).

Quality management is the act of overseeing all activities and tasks that must be accomplished to maintain a desired level of excellence. This includes the determination of a quality policy, creating and implementing quality planning and assurance, and quality control and quality improvement. It is also referred to as total quality management (TQM) (Barone, 2020). The TQM philosophy centers on two basic concepts: understanding customer needs and improving services to meet customer needs (Khursid, 1997). Studies show that improving the quality of service has valuable results for organizations and, ultimately, leads to customer satisfaction and loyalty, gaining more market share, and thus more profitability (Bell and Eisingrich in Jabbari, Dizaji, Malekolkalam, 2021). In an organization, a quality control system consists of a system of tasks, methods, and means, which an organization uses to agree and maintain the product characteristics to the expectations of the internal and external customer (Bij \& Ekert, 1999). ISO 9000 defines quality control as "a part of quality management dedicated to satisfying quality necessities" (International Organization for Standardization, 2015). Quality perception denotes the parameters that can be used to describe and assess the content and behavior of a digital library. Quality can be related not only with each sector of the content or functionality but also with the substance of the information or the appropriate service area. Some of these parameters are neutral and can be measured habitually, while others are individual and can be easily measured through user assessments (Candela et al., in Ahammad, 2021).

Academic libraries, as one of the types of libraries, play an important role in providing the information resources needed by their users and play a critical role in advancing the academic and research programs and goals of faculty members, researchers, and students, and helping to achieve qualitative and quantitative enhancements and increase the status of the university (Ahammad, 2021). However, quality control in libraries has not been widely applied yet. According to Ahammad (2021), Quality control is still seen as having less importance among libraries and library professionals. In Indonesia, we have not found many libraries that conduct quality control as part of their duties. The control is one of four components of basic function management by George R. Terry. Controlling is the fourth management process after Planning, Organizing, and Actuating (POAC) but does not mean that it is the least important. The control process also provides some measures of the quality of the planning, and leading process (Jabnoun, 2002). According to Dakhi (in Rama et al. 2019), the POAC function itself in an organization is to increase effectiveness and the efficiency of an organization in achieving its goals. 
Therefore, to explain how quality control has an impact on library management research should be conducted. We research Library X, which is an academic library that already applied quality control in its book processing activities. Book processing activities are a series of tasks or operations. Before items can be shelved and circulated from the library, they need to be physically prepared (Shoeb, 2015). Book processing in library $\mathrm{X}$ includes but is not limited to inputting data bibliography, cataloging, scanning and uploading book cover and table of content, and book release. So the book will appear in the library's online catalogs, which is an activity in book processing that is measured and analyzed in quality control data. A study listed some user expectations from the online catalog including the creation of a single catalog representing the complete library holdings of both old and new materials, the fullness of records, subjects approach, authority control, etc. (Khursid, 1997). Because those activities determine whether library users will find the book they need in the library's online catalogs and meet their expectations.

Previous research explained more about Total Quality Management or Quality Service in library, but we have not found any research about quality management in book collection retrieval in library especially in academic library. Only a few research tell about quality management or quality control in the cataloging area. An article mentioned TQM in cataloging entitled "The Application of TQM in cataloging", (1997). The paper showed the application of TQM in cataloging operations. The methods applied by libraries to identify user needs and improve service to meet user needs in cataloging and related area by applying TQM principles. But not all TQM tools such as spreadsheet and flowchart have been applied yet, therefore may also need to be reviewed for their possible application in cataloging operations (Khursid, 1997). Another research entitled "Is it necessary: quality control in cataloging?", (2018). This research described their process and workflow for the quality control of tangible and electronic resources. It also discussed why quality control is performed at the University of South Alabama. The founding of this research is the importance of training cataloging staff on current cataloging rules and practices as a preventive measure to reduce mistakes is an essential part of the process. The ultimate goal of quality control is to eliminate errors and ensure the library's resources are accessible (Nero \& He, 2018).

Quality control in the area of cataloging should get the attention of every academic library. Based on that the objectives, this research will 1) identify how the process of quality control, 2) analyze the result generated from quality control of book processing activities, and 3) find out how it will be beneficial for the organization. As already known, book processing activities are intellectual activities in libraries that are very complex related to library material content. Book processing activities are also related to the library vision and mission, interest, and consumer behavior to meet library users' needs in the concept and its knowledge development (Perpustakaan Nasional RI, 2013).

\section{RESEARCH METHODOLOGY}

The research approach used is qualitative research. This Research observed book processing activities and how its quality control was carried out to identify the process then analyze the result generated from quality control to give a certain view for book processing in Library X. Qualitative research is research designed to explain to the researcher how (process), and why (reason) certain things happen as they appear. This paper is a case study. According to Patton in J. R. Raco (2010), the case study method is a study of the specificity and complexity of a single case and seeks to understand the case in a particular context, situation, and time. In addition, Stake in Creswell (2003), 
explains that if case study research method also allows researchers to collect detailed information using various data collection methods within a certain time. Data collection techniques for this research use more than 1 method, which is Document analysis, Observation, and Interview. The research subject is Library X. The object of the research is quality management in libraries in terms of Book Collection Retrieval in Academic Library for the last 3 years (2018-2020). The data were gathered through document analysis, observation, interviews. Documents are written records of various events in the past (Raco, 2010). Document analysis is a process where the writer searches for and reads the literature that can be used as a basis for the research. Analyzed documents are cataloging activities or quality control book processing reports. Because it records information about book processing activities in detail, such as how it conducts or what is being missed at the process in library $X$ in 2018-2020. the researcher observed the Online Catalog in the library, and the process of book processing, include cataloging printed books, to find out errors that might occur in the process so that there were inaccuracies in the data of book collections in the online catalog, also to compare the document quality control with the actual errors in book processing

According to Esterberg in Sugiyono (2008), the interview is a meeting of two people to exchange information and ideas through question and answer, so the meaning can be constructed in a particular topic. Researchers use judgment sampling methods for deciding the interviewee, where respondents were selected by the researcher to confirm some criteria (Cooper \& Schindler, 2014). In that way, the researcher has the freedom to determine according to the respondent's criteria needed in the study. The criteria for respondents who were selected by the researcher were cataloging librarian and printed book processing staff at Library $\mathrm{X}$ who had worked in that position for at least 3 years. From the total of 6 librarians and book processing staff at library X, there are 1 cataloger and 2 book processing staff who meet these criteria. The semi-structured interview technique was chosen to make the interview process can be conducted more freely and casually, and remain in the context desired by the researcher. During the interview, the researcher is digging for information about their experience in book processing activities, such as how it was conducted, constraints, and how the quality control improves their work.

Data analysis was carried out by collecting all data related to the book processing process in Library X. Data was collected in documents, observations, and interviews. All data were reduced according to the needs of the researcher. The data is presented in the form of graphs, tables, and explanations in the research results. So the researchers can conclude from their research results. it is fitted with data analysis activities according to Miles and Huberman quoted by Uber Silalahi in his book Social Research Methods, which states that data analysis activities consist of 3 activity flows simultaneously, namely data reduction, data presentation, and conclusion drawing or verification (Silalahi, 2009).

\section{RESULTS AND DISCUSSION}

\section{Book Processing Activities in Library $X$}

Book processing activities in Library $\mathrm{X}$ consisted of complete bibliographic data, cataloging activities, scan and uploading cover and table of contents of the books, stamping the book to show ownership of the library, putting due date slip on the back of the books, putting a sticker of book signage such as library book number, barcode, and call number, covering the book with plastic book cover, activate the tagging book and release it in library online catalog. the researcher will explain the process further below. 
According to Odunola, et al. (2019), "Cataloguing is a structured arrangement of the bibliographic details of all the information sources available in a library. It produces an inventory that serves as access points to the library resources." The purpose of cataloging is all library materials identified and easy to retrieve. In the processing and cataloging book activities at Library $\mathrm{X}$, the cataloging librarian is tasked with carrying out descriptive cataloging and subject cataloging.

distinguish it from other works by the same author or of $\mathrm{t}$ subject. The item's elements (e.g. title, persons associa

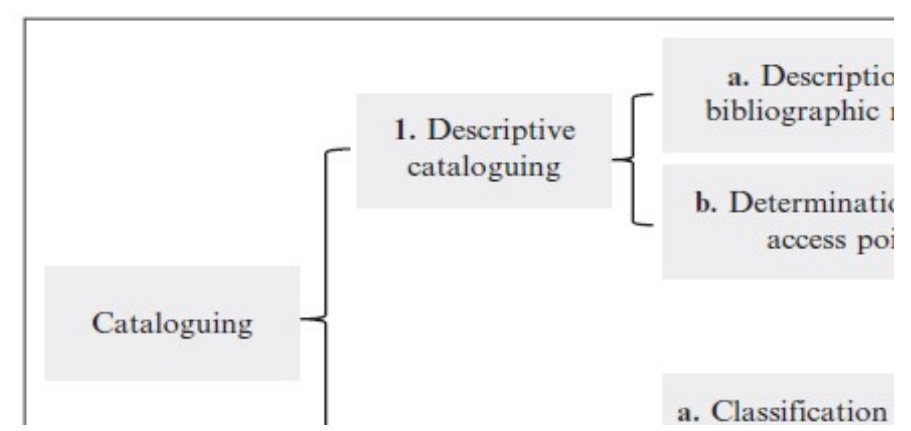

Figure 1. Cataloging Division

Source: Lazarinis, 2015

In descriptive cataloging, the cataloging librarian enters the bibliographic data of books into the automated cataloging system according to the descriptive cataloging rules listed in Anglo American Cataloging Rules 2 (AACR2), then determines the access point. In the descriptive cataloging, the bibliographic data entered include title, author, edition, type of library material, publisher, year of publication, the physical size of the book and number of pages, series (if any), notes, and ISBN. This is in line with the 8 data elements in the ISBD, namely title and statement of authorship, edition, material (type of publication), publication description, distribution, etc., physical description, series, notes, and standard number (if any), and statement of availability. (IFLA, 2004).

The descriptive cataloging process at Library $\mathrm{X}$ also includes additional detailed information such as an illustration of the front cover image of the book from the scanned book cover. This is in line with Read (2003), which states that a bibliographic record can contain attachment information in addition to bibliographic descriptions and access points. The attachment contains additional information in the form of abstracts, bibliography, images or sounds, URL links, and so on (Read, 2003). Library X also adds a bibliography, book cover, and information on supplements or additional materials that complement the information in the book, when cataloging is carried out.

While in subject cataloging works, librarians conduct subject analysis to determine the number of book classifications and subject headings based on the title, summary, and table of content of the book. The book classification number is determined based on DDC23 (Dewey Decimal Classification 23), and the subject heading determination is based on the Library Congress Subject Headings (LCSH). After the cataloging librarian carries out cataloging, the library material processing staff performs technical activities in the processing of library materials. The library material processing staff at library $\mathrm{X}$ consists of 1 book processing staff and 2 periodicals and preservation staff who are seconded in the book processing section. The division of tasks is to attach the book return date paper, book sticker, barcode, RFID, and book call number, scan the cover and 
table of contents of the book, also stamp the library logo, this activity is carried out by the book processing staff. Then cover the book, carried out by assistant staff 1 and 2.

The next process is carried out by the Library $\mathrm{X}$ cataloger, namely activating the RFID (Radio Frequency Identification) contained in the book to maximize the security of library collections. Then, the cataloger releases the book's bibliographic data. This activity serves to display bibliographic data of books that have been cataloged, in the online catalog belong to Library X. So users who need these books can find them through the online catalog. Furthermore, the cover and table of contents of the book which had previously been scanned on the technical activities of the processing staff were uploaded to the online catalog of X library by the cataloger. So that users can see, get an overview of the cover and contents of the book when searching for books in online catalogs.

\section{Analysis of Quality Control Data}

To analyze the results from quality control of book processing activities, and find out how it will be beneficial for the organization, the researcher evaluates the effectiveness of cataloging in Library $\mathrm{X}$ by examining the quality control document data of cataloging and book processing activities for the last 3 years. However, not all components of data quality control will be used, because the data covers the entire process of cataloging and processing books in library $\mathrm{X}$. So in this study, researchers will only focus on 3 components of data quality control of book processing activities in the library $\mathrm{X}$ that related to book retrieval in library's online catalog. Included in the cataloging activities for the data quality control component in library $\mathrm{X}$ are inputting cataloging data, descriptive and subject cataloging (1), scanning and uploading book covers and table of contents(2), book releases to display the data in the library's online catalog (3).

This is in line with the explanations of Odunola (2019) and Read (2003) regarding cataloging and information contained in bibliographic records. According to Odunola, et al (2019), cataloging is a structured bibliographical arrangement of collections owned by the library, while according to Read (2003) bibliographic records contain information in 3 categories, namely bibliographic descriptions, access points, and attachments of additional information such as abstracts, bibliography, images or sounds, URL links, and so on. The results of the book cataloging quality control in library X in 2018-2020 can be seen in Table 1 below.

Table 1. Summary of Library X Book Processing Quality Control Data on 2018-2020

\begin{tabular}{lccccccc}
\hline Year & $\begin{array}{c}\text { Number of } \\
\text { book copies }\end{array}$ & $\begin{array}{c}\text { Cataloging and input of data } \\
\text { bibliographic } \\
\text { Total correct }\end{array}$ & $\begin{array}{c}\text { Scan, upload cover and } \\
\text { table of contents }\end{array}$ & \multicolumn{2}{c}{$\begin{array}{c}\text { Book release in online } \\
\text { catalog }\end{array}$} \\
\hline $\mathbf{2 0 1 8}$ & 1127 & 991 & 136 & 1119 & 8 & 1127 & $\begin{array}{c}\text { Total } \\
\text { Total } \\
\text { correct }\end{array}$ \\
$\mathbf{2 0 1 9}$ & 803 & 660 & 143 & 755 & 48 & 795 & 8 \\
$\mathbf{2 0 2 0}$ & 402 & 352 & 50 & 376 & 26 & 397 & 5 \\
Total & $\mathbf{2 3 3 2}$ & $\mathbf{2 0 0 3}$ & $\mathbf{3 2 9}$ & $\mathbf{2 2 5 0}$ & $\mathbf{8 2}$ & $\mathbf{2 3 1 9}$ & $\mathbf{1 3}$ \\
\hline
\end{tabular}

Source: Internal Document of Library X (2018 -2020)

Table 1 above shows the results of the accuracy of cataloging carried out in library $\mathrm{X}$ in the last 3 years. The number of book copies shows the total number of cataloged 
book copies is 2332 copies for the last 3 years. The total number of cataloged books in 2018 was 1127 copies. Then there was a decrease in the number of books cataloged in 2019 by 324 copies with a total catalog of 803 copies and a decrease in 2020 by 725 copies with a total catalog of only 402 copies. According to the acquisition librarian of Library $\mathrm{X}$ who we interviewed, the decrease in the number of books in collection procurement activities was due to the transition of Library $\mathrm{X}$ which began to buy books in the format of electronic books (e-books). So they are not cataloged in the same way as printed books. And the library crisis is because of Pandemic Covid-19, which makes the library's operation not optimal.

Details of the total accuracy of cataloging per year as measured from cataloging and inputting bibliographic data, scanning and uploading covers and table of contents, and book releases in online catalogs, can be seen in Figure 2.

Figure 2. Chart of Library X Book Processing Quality Control Data on 2018-2020

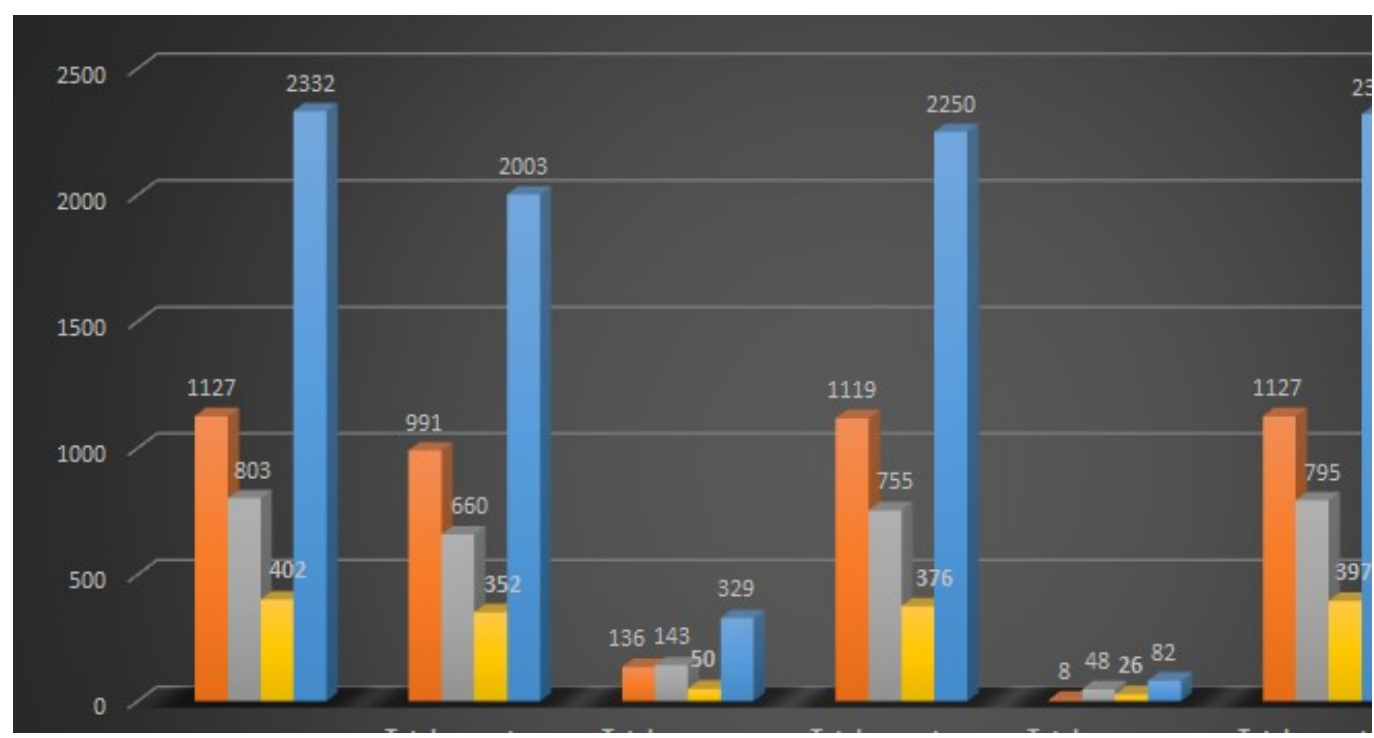

Source: Internal Document of Library X (2018-2020)

Table 2. Summary by Percentage of Library X Book Processing Quality Control Data on 2018-2020

\begin{tabular}{ccccccc}
\hline Year & \multicolumn{2}{c}{$\begin{array}{c}\text { Cataloging and input of data } \\
\text { bibliographic }\end{array}$} & \multicolumn{2}{c}{$\begin{array}{c}\text { Scan, upload cover, and } \\
\text { table of contents }\end{array}$} & \multicolumn{2}{c}{$\begin{array}{c}\text { Book release in the online } \\
\text { catalog }\end{array}$} \\
& Total correct & Total wrong & $\begin{array}{c}\text { Total } \\
\text { correct }\end{array}$ & $\begin{array}{c}\text { Total } \\
\text { wrong }\end{array}$ & $\begin{array}{c}\text { Total } \\
\text { correct }\end{array}$ & Total wrong \\
\hline 2018 & $88 \%$ & $12 \%$ & $99 \%$ & $1 \%$ & $100 \%$ & $0 \%$ \\
2019 & $82 \%$ & $18 \%$ & $94 \%$ & $6 \%$ & $99 \%$ & $1 \%$ \\
2020 & $88 \%$ & $12 \%$ & $94 \%$ & $6 \%$ & $99 \%$ & $1 \%$ \\
\hline
\end{tabular}

Source: Internal Document of Library X (2018-2020)

Figure 2 above is a comparison chart of the number of correct and incorrect cataloging stages per book and per year. Table 2 above also shows in the stage of cataloging and inputting book bibliographic data shows that the number of cataloged book copies and correctly input bibliography decreased by 6\%. From $88 \%$ or 991 copies were cataloged and bibliographic input correctly in 2018, from the total number of 
books processed, namely 1127 copies, to $82 \%$ or 660 copies were correct from the total 803 copies cataloged. Meanwhile, an increase of $6 \%$ occurred in the number of incorrectly cataloged copies of books in 2018 and 2019. From the previous 136 incorrect copies in 2018 to 143 incorrect copies in 2019. In 2020, there was an increase in the percentage of the number of correctly cataloged copies. by $6 \%$ from 2019 , which is $88 \%$ or 352 copies. So the percentage of textbooks that are wrongly cataloged also decreases by $6 \%$ or only 50 copies of the total 402 copies of books cataloged.

At the stage of scanning and uploading the cover and table of contents of the book, the copies that were processed correctly in 2018 were 1119 copies or $99 \%$ of the total number of 1127 copies. Meanwhile, in 2019 the number of copies that were properly processed was 755 copies or $94 \%$ of the total 803 copies scanned and uploaded. With a $5 \%$ reduction in the percentage of correctly processed books. Meanwhile, the increase in the percentage of incorrect copies occurred at this stage between those years, which was $5.2 \%$. The number of incorrectly scanned copies and uploaded covers and table of contents increased from 8 copies in 2018 to 48 copies in 2019. In 2020, the number of accurate scans and uploads of covers and table of contents for books is 376 copies out of a total of 402 copies, with the total percentage processed correctly is the same as the previous year which is $94 \%$. At the stage of releasing books in the online catalog, the percentage of books that were released correctly was 100\% in 2018 and $99 \%$ in 2019 . With a percentage decrease of $1 \%$. On the other hand, the percentage of copies that were released incorrectly was $0 \%$ in 2018 , and $1 \%$ in 2019 , or an increase of $1 \%$, equal to the percentage of the number of books that were released correctly in 2020.

From the summary of Library X Book Processing quality control data on 20182020 that carried out concerning collection retrieval, namely descriptive and subject cataloging as well as bibliographic data input (1), scanning, uploading book covers, and table of contents (2), and releasing book data to the library's online catalog (3), researcher analysis if the descriptive and subject cataloging activities, as well as bibliographic data input (1), have the highest number of errors in the process compared to other cataloging activities. Total errors in the 3 book cataloging processes evaluated over the last 3 years, namely 329 errors in the descriptive and subject cataloging process as well as bibliographic data input, 82 errors in the scanning process, uploading the cover and table of contents of the book, and 13 errors in the process of releasing book data to library online catalog. Obtained a total of all errors in the cataloging process a total of 424 process errors. Based on this, the highest percentage of errors during the book cataloging process occurred during the descriptive and subject cataloging process as well as bibliographic data input, which was 329 errors or $78 \%$ of the total errors that occurred during the 3 processes evaluated. According to the results of interviews, this happens because this process requires higher accuracy and understanding compared to other processes.

Errors when descriptives cataloging mostly occur due to bibliographic descriptions that do not match the book data. These include the determination of the place of publication which is confused with the country of publication of the book, as well as the year of reprint which is often considered the year of publication. In addition, based on the researcher's observations, the determination and writing of inappropriate main and sub-titles, and the writing of the author's name of more than 3 people who did not use et.al., also forgot to reverse the author's name, became a considerable error when conducting cataloging evaluations. In subject cataloging, errors often occur when determining the wrong subject, so the classification number is also inaccurate. 
Meanwhile, for bibliographic input, errors often occur due to typos or incorrect use of punctuation when inputting bibliographic data.

In addition, although scanning and uploading book covers, table of contents, and releasing books in online catalogs (2), the process is more technical and relatively easier. However, there are still errors in the scan and upload of books by 6\% on 2019 and 2020 quality control data. Usually, this error is caused by not being careful when uploading a book. So the title of the book and the cover or table of contents uploaded is different. In addition, errors when scanning the table of contents also often occur. So, during observation, it is often found that the table of contents is inappropriate, unreadable, or the scan position is too tilted, so it needs to be re-scanned for comfortable reading. Then errors in book releases (3) usually occur when the catalog forgets to release the book, so it does not appear in the online library catalog. But errors in book releases count the least of all book processing activities that we measured, it is only $1 \%$ from all books that are being processed. However, considering that the book release process is relatively very easy, which is simply entering the book's registration number into the system, this error should be very avoidable.

In 2019, although the number of books cataloged per copy was less than in 2018. The percentage of errors in cataloging, scanning, and uploading covers, and table of contents, as well as book releases in online catalogs, increased by an average of almost $4 \%$. This happened because there was a change of catalogers in Library X. The high level of understanding required when cataloging, and the process of adapting to cataloging procedures and rules in Library X, also caused errors in cataloging to increase when performed by new catalogers. After new catalogers began to adapt to the cataloging system carried out at Library X in 2020, the percentage accuracy of cataloging and inputting bibliographic data increased by $6 \%$, but the percentage of accuracy in scanning $\&$ uploading covers and table of contents, as well as book releases in the online catalog remained the same as in 2019 namely $94 \%$ and $99 \%$ of the total cataloged books.

\section{CONCLUSION}

The quality control system consists of a system of tasks, methods, and means, which an organization uses to agree and maintain the product characteristics to the expectations of the internal and external customer. Academic Library X always does quality control for Book processing activities every time their finishing Book Processing activities for the new book comes to the library, a minimum of 10 books at one time. In the quality control process, the quality control librarian will examine every book that has already been finished and is ready to be sent to the bookshelves, to make sure all books sent out from the book processing room are qualified, and not missed any of the processes. The result of the quality control book was directly sent to the cataloguer librarian as the person in charge of book processing activities and reported to the Collection Development Head. The result was used by the Cataloguer Librarian to re-check all the finding errors on certain books that already underwent quality control. Cataloguer librarians do corrections on the finding errors before the book is sent to Bookshelves.

So quality control on Book Processing Activities in Academic Library X, beneficial to improve the quality of the book that already underwent processing activities and its quality control. Human or technical errors in the process can be minimized or even no errors at all when books are sent out to the shelves for service to the user. Quality control data is not only beneficial to know errors in a certain book but also can be used as a performance evaluation for staff and cataloging librarians when they do their duty on book processing activities. Quality control data is also used for checking the errors 
that often appear on quality control data, so the librarian can analyze and find solutions for the problems immediately. Another benefit for conducting quality control especially on book processing, it will minimize errors on activation tag RFID that will increase lost books in libraries. Quality control in book processing activities will increase book retrieval in the library. Because library users can find the books that they need in the library online catalog. A good retrieval in library online catalog also can increase library catalog reliability as a reference gate for users and librarians to find books and other resources in the library. Quality control made sure all books that the library had released on the library's online catalog, so users could find the books they needed by searching those books by subject, title, etc. in the library online catalog. So quality control makes sure all books in the library can be found easily.

Quality control, either for book processing or another activity such as acquisition or service in libraries will increase the quality of the libraries' performance in any kind of way. It will be beneficial for the library to increase customer satisfaction. Then quality control data will give comprehensive evaluation either for humans, processes, and systems that help the library conduct its duty to provide their user needs and expectations. Since it illustrates how the process going on in the library, quality control can be used as a mirror to describe the library working atmosphere. And can be used for giving motivation to all librarians and staff to give better service and performance for their users

\section{REFERENCES}

Ahammad, N. (2021). Quality control (QC) of an institutional repository: a hands-on. Collection and Curation, 1-8.

Barone, A. (2020, Juli 28). Quality Management. Diambil kembali dari Investopedia: https://www.investopedia.com/terms/q/quality-management.asp

Bij, H. v., \& Ekert, H. v. (1999). Interaction between production control and quality control. International Journal of Operations \& Production Management, 19(7), 674-690.

Cooper, D. R., \& Schindler, P. S. (2013). Business Research Methods (12 ed.). New York: McGraw-Hill Education.

Creswell, J. W. (2003). Research Design: Qualitative, Quantitative, and Mixed Methods Approaches. California: SAGE Publications.

IFLA. (2004). ISBD(G) : General International Standard Bibliographic Description. International Federation of Library Asociation and Institutions (IFLA).

International Organization for Standardization. (2015). Quality management principles. Geneva: International Organization for Standardization.

Jabbari, L., Dizaji, A. J., \& Malekolkalami, M. (2021). Gap assessment and comparison of the quality of services between central libraries of the University of Tehran and Allameh Tabataba'i University. Performance Measurement and Metrics, 22(2), 89-105.

Jabnoun, N. (2002). Control process for the quality management and quality assurance. Work Study, 51(4), 182-190.

Khursid, Z. (1997). The application of TQM in cataloguing. Library Management, 18(6), hal. 274-279. 
Lazarinis, F. (2015). Cataloguing and Classification : an introduction to AACR2, RDA, DDC, LCC, LCSH, and MARC 21 Standrards. Waltham: Elsevier.

Nero, M. D., \& He, J. (2018). Is it Necessary: Quality Control in Cataloging? International Journal of Librarianship, 3(2), 85-95.

Odunola, O. A. (2019). Evaluation of Automated Cataloguing System in Academic Libraries in Oyo State Nigeria. Library Philosophy and Practice, 1-13.

Perpustakaan Nasional RI. (2013). Pedoman pengolahan bahan perpustakaan Perpustakaan Nasional RI. Jakarta: Perpustakaan Nasional RI.

Rama, V. O., Astawa, I. K., Wendri, I. G., \& Mudana, I. G. (2019). Room Allotment Management to Increase Room Occupancy and its Implication to Hotel Management Strategy. BALI MEMBANGUN BALI, 2(2), 75-82.

Raco, J. R. (2010). Metode Penelitian Kualitatif: Jenis Karakteristik dan Keunggulannya. Jakarta: Grasindo.

Raju, J., \& Raju, R. (2006). Descriptive and subject cataloguing : a workbook. Oxford: Chandos Publishing.

Read, J. M. (2003). Cataloguing Without Tears: Managing knowledge in the information society. Oxford: Chandos Publishing.

Shoeb, M. Z. (2015). Processing library materials (Data entry, Barcode Creation, Call. No., Printing, Testing, \& Pasting. Bangladesh: Independent University.

Silalahi, U. (2009). Metode Penelitian Sosial. Etika Widyatama.

Sugiyono. (2008). Memahami Penelitian Kualitatif. Jakarta: CV. Alfabeta. 